\title{
Development of LAMP and Real-Time PCR Methods for the Rapid Detection of Xylella fastidiosa for Quarantine and Field Applications
}

\author{
S. J. Harper, L. I. Ward, and G. R. G. Clover
}

Plant Health and Environment Laboratory, Investigation and Diagnostic Centre, MAF Biosecurity New Zealand, P.O. Box 2095, Auckland 1140, New Zealand.

Accepted for publication 18 August 2010.

\section{ABSTRACT}

Harper, S. J., Ward, L. I., and Clover, G. R. G. 2010. Development of LAMP and real-time PCR methods for the rapid detection of Xylella fastidiosa for quarantine and field applications. Phytopathology 100:1282-1288.

Xylella fastidiosa is a regulated plant pathogen in many parts of the world. To increase diagnostic capability of $X$. fastidiosa in the field, a loop-mediated isothermal amplification (LAMP) and real-time polymerase chain reaction (PCR) assay were developed to the rimM gene of $X$. fastidiosa and evaluated for specificity and sensitivity. Both assays were more robust than existing published assays for detection of $X$. fastidiosa when screened against 20 isolates representing the four major subgroups of the bacterium from a range of host species. No crossreaction was observed with DNA from healthy hosts or other bacterial species. The LAMP and real-time assays could detect 250 and 10 copies of the rimM gene, respectively, and real-time sensitivity was comparable with an existing published real-time PCR assay. Hydroxynapthol blue was evaluated as an endpoint detection method for LAMP. When at least 500 copies of target template were present, there was a noticeable color change indicating the presence of the bacterium. Techniques suitable for DNA extraction from plant tissue in situ were compared with a standard silica-column-based laboratory extraction method. A portable PickPen and magnetic bead system could be used to successfully extract DNA from infected tissue and could be used in conjunction with LAMP in the field.

Additional keywords: diagnostics.
Xylella fastidiosa (39) is a bacterial plant pathogen that causes several economically important diseases, including Pierce's disease of grapevine, citrus veinal chlorosis, almond leaf scorch, phony peach, and leaf scorch on a range of ornamental plants and shade trees (10-12). X. fastidiosa is a regulated organism in many parts of the world. Leafhoppers of the subfamily Cicadellinae (Hemiptera: Cicadellidae) and spittle bugs or frog hoppers of the family Cercopidae (Hemiptera) are the most common known vectors (27). The distribution of $X$. fastidiosa is generally limited to the Americas (27), with two exceptions, in Vitis vinifera in Kosovo (1) and pear in Taiwan (18). It is thought that $X$. fastidiosa is sensitive to low temperatures, which has restricted its movement into regions with temperate climates and, in particular, cold winters (27). However, many colder parts of the world do possess one or more vector species, such as the spittlebug (Philaenus spumarius); therefore, the potential does exist for $X$. fastidiosa to spread into such areas should cold-tolerant strains, such as almond leaf scorch, become established (27). From a quarantine perspective, rapid detection and diagnosis is the key feature of any exclusion strategy.

Current assays for $X$. fastidiosa diagnosis include bacterial cell culture, conventional polymerase chain reaction (PCR) $(12,13$, 20,26,28), and real-time PCR (7,29). Although many of these methods have been used routinely in the laboratory, most of these methods are not easily transferable to the field. In addition, the PCR assay of Minsavage et al. (20) was developed over 15 years ago when there was little DNA sequence of $X$. fastidiosa available. This assay is commonly used for quarantine screening and, therefore, it is particularly important to verify that it detects all

Corresponding author: L. I. Ward; E-mail address: lisa.ward@maf.govt.nz

doi:10.1094/PHYTO-06-10-0168

(C) 2010 The American Phytopathological Society isolates of the bacterium reliably. In view of these factors, alternative methods of detection were considered.

One method that has been recently adopted for plant pathogen diagnostics is loop-mediated isothermal amplification (LAMP). Because the LAMP reaction is isothermal, it can be performed in a heat block or water bath, thereby removing the need for specialized equipment. In addition, positive amplification can be observed by colorimetric or fluorescent dyes $(9,33)$, removing the need to run gels. Both of these factors contribute to transferability to the field.

Here, we present the development and evaluation of a LAMP assay for $X$. fastidiosa to improve diagnostic capability by enabling surveillance activities, improving response times during incursions, and allowing testing of imported commodities at the border. During the development of the LAMP assay, the potential arose to develop an alternative real-time TaqMan (Applied Biosystems, Foster City, CA) PCR based on detection of the same region used for the LAMP primer design. The new TaqMan (Applied Biosystems) real-time assay was also evaluated alongside the LAMP method.

\section{MATERIALS AND METHODS}

Samples. $X$. fastidiosa cultures were obtained from commercial (DSMZ, Mannheim, Germany) and academic (Landcare Research, Auckland, New Zealand) sources. Freeze-dried X. fastidiosa-infected samples of V. vinifera, V. rotundifolia, and Quercus rubra leaves and infected blue-green sharpshooters (Graphocephala atropunctata) were obtained from Dr. R. Almeida (University of California, Berkley) and C. Chang (University of Georgia, Griffin). DNA samples of $X$. fastidiosa, extracted from a range of host species, were obtained either on FTA cards (Whatman Inc., Florham Park, NJ) or lyophilized, from Dr. L. Nunney (University of California, Riverside), Dr. C. Su (Taiwan Agricul- 
tural Chemicals Toxic Substances Research Institute, Taichung, Taiwan), and Dr. H. Coletta Filho, (Centro de Citricultura, Cordieropolis, Brazil). Spiroplasma citri DNA was obtained from Dr. R. Yokomi (United States Department of Agriculture, Parlier, CA). Finally, DNA extracts of healthy host-plant species and nontarget bacterial species were obtained from the MAF Biosecurity New Zealand nucleic acid collection.

Sample DNA extraction. Plant samples (200 mg of leaf midrib and petiole) and whole insects were ground to a fine powder in liquid nitrogen prior to extraction using the DNeasy Plant Mini Kit (Qiagen, Valencia, CA) as per published protocols (13). Samples on FTA cards (Whatman Inc.) were eluted using the Sigma Extract-N-Amp Kit (Sigma-Aldrich, St. Louis) using the manufacturer's protocol. Lyophilized cell cultures were disrupted with a Roche MagNA Lyser instrument (Roche Applied Science, Auckland, New Zealand), then extracted using DNeasy Plant Mini Kit (Qiagen) as above.

Testing alternative DNA extraction methods for field use. Two alternative DNA extraction methods that could potentially be used in the field with minimal specialized equipment were tested: the Extract-N-Amp Kit (Sigma-Aldrich) using the manufacturer's protocol and the Bio-Nobile 8-M PickPen (Bio-Nobile, Turku, Finland) using Invimag Plant DNA KFmL Mini Kit reagents (Invitek, Berlin, Germany). Samples (200 mg) of infected lyophilized petiole and leaf midrib tissue were homogenized in $2 \mathrm{ml}$ of lysis buffer P (Invitek) in sample extraction bags (BioReba, Basel, Switzerland) using a hand-roller. DNA extraction was then performed in a Nunc 96 DeepWell plate (Thermo-Fisher Scientific, Waltham, MA) using the PickPen to manipulate the magnetic beads. Briefly, $420 \mu \mathrm{l}$ of homogenized plant sap was added to the first well with $20 \mu \mathrm{l}$ of magnetic beads and $200 \mu \mathrm{l}$ of binding buffer and mixed using the PickPen (Bio-Nobile) for $3 \mathrm{~min}$. Beads were collected and transferred into $800 \mu \mathrm{l}$ of wash buffer 1 for $2 \mathrm{~min}$, followed by two washes of $2 \mathrm{~min}$ with $800 \mu \mathrm{l}$ of wash buffer 2. DNA was eluted for $3 \mathrm{~min}$ in $100 \mu \mathrm{l}$ of nucleasefree $\mathrm{H}_{2} \mathrm{O}$. DNA was stored at $-80^{\circ} \mathrm{C}$ prior to use.

Gene target selection and primer design. Using the work of Doddapaneni et al. (5) as a starting point, potential gene targets within the $X$. fastidiosa genome were assessed on the basis of sequence conservation between isolates with an arbitrary threshold of $>98 \%$ nucleotide identity, and significant sequence difference from related species in the family Xanthomonadaceae. In total, four candidate genes were selected for primer design from the data of Doddapaneni et al. (5) and an alignment of the extant genomes 9a5C, Temecula, M12, and M23 (National Center for Biotechnology Information GenBank accession numbers NC_002488, NC_004556, NC_010513, and NC_010577, respectively). These genes were annotated as per the genome of the 9a5c isolate: disulfide isomerase (XF_1834), the 16S rRNA processing protein rimM (XF_0108), a HicB-related protein (XF_1668), and a cell division protein (XF_0095). Two additional regions, citrate synthase gltA $\left(\mathrm{XF}_{-} 1535\right)$ (2) and a hypothetical protein (7) used in published assays for $X$. fastidiosa detection and diagnosis, were also selected.

All potential target regions were examined for primer design using the alignment of the $X$. fastidiosa genomes described above and the online PrimerExplorer V4 software (Eiken Chemical Co., Tokyo) with default program parameters. Viable primer sets were generated for three targets-disulfide isomerase, $\operatorname{rim} M$, and gltA-initial testing of which (data not shown) led to the adoption of the rimM primer set (Table 1) for further development and testing. The two inner primers designed, XF-FIP and XF-BIP, were modified with a TTTT linker sequence between the sense and antisense sequences to ensure loop formation, and two complimentary loop primers, XF-LF and XF-LB, were designed to accelerate strand displacement and amplification (23).

Following the selection of the LAMP primers, a set of real-time PCR primers and the associated 6 -carboxyfluorescein/Black Hole Quencher-1-labeled (6'FAM/BHQ) TaqMan (Applied Biosystems) probe (Table 1) were also designed to the rimM open reading frame (ORF) using the online RealTimeDesign software (BioSearch Technologies, Novato, CA) with the default parameters.

Optimization of the rimM LAMP assay. The LAMP protocol was developed from the method described by Varga and James (37). To optimize the LAMP reaction, the concentrations of core reagents were tested as follows: $\mathrm{MgSO}_{4}$ at 4 to $8 \mathrm{mM}$ and betaine at 0.6 to $1 \mathrm{M}$. Trehalose was examined as an alternative to betaine (30) at a concentration of 0.2 to $1 \mathrm{M}$. Reaction temperatures of 62 to $65^{\circ} \mathrm{C}$ were tested, as were optimal reaction times of 45 to $90 \mathrm{~min}$. The optimized rimM LAMP reaction was performed in a $25 \mu \mathrm{l}$ reaction volume containing $1 \times$ ThermoPol buffer $(20 \mathrm{mM}$ Tris- $\mathrm{HCl}, 10 \mathrm{mM}\left(\mathrm{NH}_{4}\right)_{2} \mathrm{SO}_{4}, 10 \mathrm{mM} \mathrm{KCl}, 2 \mathrm{mM} \mathrm{MgSO}_{4}$, and $0.1 \%$ Triton $\mathrm{X}-100, \mathrm{pH} 8.8$ ) (New England Biolabs, Beverly, MA) with additional $\mathrm{MgSO}_{4}$ to a total final concentration of $8 \mathrm{mM}$, $0.8 \mathrm{M}$ Betaine, $1.4 \mathrm{mM}$ each dNTP, $0.2 \mu \mathrm{M}$ outer (XF-F3/XF-B3) primers, $0.8 \mu \mathrm{M}$ loop (XF-LF/XF-LB) primers, and $1.6 \mu \mathrm{M}$ inner primers (XF-FIP/XF-BIP), with eight units of Bst DNA polymerase (New England Biolabs) and $2 \mu$ of total DNA extract (of 100 to $300 \mathrm{ng}$ of total DNA, depending on sample type). The reaction was incubated at $65^{\circ} \mathrm{C}$ for $60 \mathrm{~min}$, followed by a $2 \mathrm{~min}$ enzyme inactivation step at $80^{\circ} \mathrm{C}$ in an ABI 9700 thermocycler (Applied Biosystems). Successful amplification of $X$. fastidiosa DNA was confirmed by agarose gel electrophoresis of a $15 \mu \mathrm{l}$ aliquot of the LAMP reaction. Target specificity of the LAMP assay was confirmed by sequencing of the major amplification product using the XF-LF and XF-LB primers using the Sanger method; sequencing was performed by Ecogene (Auckland, New Zealand).

Evaluation of hydroxynapthol blue. The addition of hydroxynapthol blue (HNB) (Sigma-Aldrich) as a colorimetric means of indicating positive reactions (9) was assessed. HNB was added at

TABLE 1. Primers designed for the amplification of the partial rimM open reading frame of Xylella fastidiosa by loop-mediated isothermal amplification (LAMP) and real-time polymerase chain reaction ${ }^{\mathrm{b}}$

\begin{tabular}{llc}
\hline Assay, primer & \multicolumn{1}{c}{ Sequence $\left(5^{\prime}-3^{\prime}\right)$} & Binding site \\
\hline qRT-PCR & & $106,620-106,602$ \\
XF-F & CACGGCTGGTAACGGAAGA & $106,550-106,570$ \\
XF-R & GGGTTGCGTGGTGAAATCAAG & $106,601-106,584$ \\
XF-P & TCGCATCCCGTGGCTCAGTCC & $106,884-106,865$ \\
LAMP & & $106,676-106,694$ \\
XF-F3 & CCGTTGGAAAACAGATGGGA & $106,788-106,862$ \\
XF-B3 & GAGACTGGCAAGCGTTTGA & $106,773-106,695$ \\
XF-FIP & ACCCCGACGAGTATTACTGGGTTTTCGCTACCGAGAACCACAC & $106,824-106,844$ \\
XF-BIP & GCGCTGCGTGGCACATAGATTTTTGCAACCTTTCCTGGCATCAA & $106,753-106,735$ \\
XF-LF & TGCAAGTACACACCCTTGAAG & \\
XF-LB & TTCCGTACCACAGATCGCT &
\end{tabular}

a LAMP primer binding sites are given for the genome of isolate 9a5C (GenBank accession no. NC_002488).

${ }^{b}$ Quantitative reverse-transcription polymerase chain reaction. 
a concentration of $150 \mu \mathrm{M}$ as described by Goto et al. (9) in a final reaction volume of $25 \mu \mathrm{l}$. The rate of color change from purple to blue was assessed from 45 to $75 \mathrm{~min}$ at 15 -min intervals at $65^{\circ} \mathrm{C}$ using a dilution series of $X$. fastidiosa DNA extracted from lyophilized cultured cells (DSMZ), of 1,000, 500, 250, 125, and 10 copies per reaction diluted in clean (uninfected) $V$. vinifera total DNA extract; concentration was calculated using an estimated genome size of $2.5 \mathrm{MB}$ with the formula copies per microliter $=\left(\right.$ concentration in nanograms $\left.\times 6.023 \times 10^{23}\right) /$ (genome length $\times 1 \times 10^{9} \times 650$ ).

Real-time PCR optimization. The $X$. fastidiosa rimM realtime PCR assay designed in this study was optimized for primer and TaqMan (Applied Biosystems) probe concentration, $\mathrm{Mg}^{2+}$ and thermocycling conditions using Invitrogen quantitative (q)PCR Supermix-UDG (Invitrogen, Carlsbad CA), and a Bio-Rad CFX96 gradient real-time thermocycler (Bio-Rad Laboratories, Hercules, CA). Final optimized reaction conditions were as follows: real-time PCR reactions were done in $20-\mu$ l reaction volumes containing $10 \mu \mathrm{l}$ of $2 \times$ qPCR Supermix-UDG (Invitrogen) with a final concentration of $4 \mathrm{mM} \mathrm{MgCl} 2,300 \mathrm{nM} \mathrm{X}$. fastidiosa sense (XF-F) and antisense (XF-R) primers, $100 \mathrm{nM}$ 6'FAM/BHQ-1labeled XF-P probe, bovine serum albumin (BSA) at $300 \mathrm{ng} / \mu \mathrm{l}$ (Sigma-Aldrich), and $2 \mu \mathrm{l}$ of total DNA template. Optimal thermocycling conditions were as follows: $50^{\circ} \mathrm{C}$ for $2 \mathrm{~min}$ and $94^{\circ} \mathrm{C}$ for $2 \mathrm{~min}$, then 40 cycles of $94^{\circ} \mathrm{C}$ for $10 \mathrm{~s}$ and $62^{\circ} \mathrm{C}$ for $40 \mathrm{~s}$. All samples were amplified in triplicate. Threshold values were applied automatically by the CFX Manager V1.6 software (BioRad Laboratories). Reaction efficiency was calculated using the dilution series described above for HNB evaluation, with the formula $E=10^{(-1 / \text { slope })}$.

Comparison to extant methods. The sensitivity, specificity, and reliability of the rimM LAMP and real-time PCR assays were compared with published $X$. fastidiosa conventional PCR (20) and real-time PCR (7) assays. DNA from 20 isolates representing the four major subgroups of $X$. fastidiosa and the phylogenetically distinct pear leaf scorch isolate was tested with all assays, and positive amplification was determined by either the presence of a band of the expected size for LAMP and conventional PCR or a crossing threshold $(\mathrm{Ct})$ value of $<38$ cycles for the real-time PCR assays. In addition, infected blue-green sharpshooters were also tested to determine whether the designed assays would amplify $X$. fastidiosa from the vector; healthy sharpshooters could not be sourced. Finally, DNA was extracted from cultures and plant and insect tissue as described above. DNA from nontarget bacterial species and healthy plant hosts were tested to check for crossreactivity (Table 2). The sensitivity of each assay was determined using the dilution series described earlier. Confirmation of the copy numbers of the dilution series and an estimation of target concentration in the $X$. fastidiosa-positive sample extracts were obtained by absolute real-time PCR using the assay of Francis et al. (7) against a cloned DNA standard. Real-time PCR and LAMP assays were performed in triplicate, while conventional PCR was performed in duplicate.

Conventional PCR reactions were done in 20- $\mu$ l reaction volumes containing $50 \mathrm{mM} \mathrm{KCl}, 10 \mathrm{mM}$ Tris- $\mathrm{HCl}, 1.5 \mathrm{mM}$ $\mathrm{MgCl}_{2}, 250 \mathrm{nM}$ forward and reverse primers, $200 \mathrm{nM} \mathrm{dNTPs}$, 1 unit of Platinum Taq DNA polymerase (Invitrogen), and $2 \mu \mathrm{l}$ of DNA template in an ABI 9700 thermocycler (Applied Biosystems). Cycling conditions consisted of $3 \mathrm{~min}$ at $94^{\circ} \mathrm{C}$; followed by 40 cycles of $94^{\circ} \mathrm{C}$ for $30 \mathrm{~s}, 55^{\circ} \mathrm{C}$ for $30 \mathrm{~s}$, and $68^{\circ} \mathrm{C}$ for $30 \mathrm{~s}$; with a final extension step of $5 \mathrm{~min}$ at $68^{\circ} \mathrm{C}$. PCR products were visualized on a $1.5 \%$ agarose gel using a $15-\mu$ l aliquot of PCR reaction.

The real-time PCR assay of Francis et al. (7) was performed with a Bio-Rad CFX-96 thermocycler (Bio-Rad Laboratories), using a reaction volume of $20 \mu \mathrm{l}$ containing $2 \times$ qPCR SupermixUDG (Invitrogen) with a final concentration of $4.5 \mathrm{mM} \mathrm{MgCl}$, $300 \mathrm{nM} \mathrm{X}$. fastidiosa sense and antisense primers, $100 \mathrm{nM}$
6'FAM-labeled probe, BSA at $300 \mathrm{ng} / \mu \mathrm{l}$, and $2 \mu \mathrm{l}$ of DNA template. Thermocycling conditions were $50^{\circ} \mathrm{C}$ for $2 \mathrm{~min}$ and $94^{\circ} \mathrm{C}$ for $2 \mathrm{~min}$, then 40 cycles of $94^{\circ} \mathrm{C}$ for $10 \mathrm{~s}$ and $60^{\circ} \mathrm{C}$ for $45 \mathrm{~s}$. The optimized rimM-specific LAMP and real-time PCR assays were performed as described above.

\section{RESULTS}

Primer design. A conserved region of the $\operatorname{rim} M$ gene was selected for primer design to ensure consistent and reproducible amplification of $X$. fastidiosa. The other genes considered had unacceptable homology to non-target organisms in silico or were unable to support LAMP primer design. During the initial primer screening, LAMP primer sets for the disulfide isomerase and gltA failed to amplify DNA from many of the $X$. fastidiosa isolates tested and were therefore discarded (data not shown).

Optimization of the rimM LAMP assay. Optimization of the rimM LAMP assay indicated that high-performance liquid chromatography (HPLC) purification of the two large inner primers was necessary for reaction efficacy and sensitivity, as previously observed by Varga and James (37). The remaining outer and loop primers functioned with standard desalted purification. Trehalose was examined as an alternative to betaine in the reaction; however, it proved unable to support LAMP amplification and, therefore, was discarded (data not shown). Optimized reaction conditions are given in the Methods section.

Using a serial dilution of $X$. fastidiosa DNA (diluted in $V$. vinifera DNA extract) and varying the incubation time from 45 to $90 \mathrm{~min}$, an incubation time of $60 \mathrm{~min}$ at $65^{\circ} \mathrm{C}$ was found to be sufficient to amplify all isolates tested and consistently amplify a dilution of 500 copies of template per reaction. Inconsistent amplification was sometimes observed with a starting dilution of 250 copies; however, increasing incubation to $75 \mathrm{~min}$ improved the reliability of DNA amplification (Table 3). Extending the incubation time past $75 \mathrm{~min}$ gave no further increase in sensitivity. Agarose gel electrophoresis of the rimM LAMP products produced a ladder pattern with a high-titer band of the major amplification product (180 bp) and several faint, larger products (Fig. 1). This banding pattern is typical when using HPLCpurified primers; use of non-HPLC-purified primers results in a lower titer of the main amplification product and more nonspecific laddering (data not shown). Direct sequencing of the major amplification product using the loop primers indicated that the primers were specific to bases 106,752 to 106,862 of the $X$. fastidiosa isolate 9a5C genome (NC_002488), within the rimM gene as designed.

Evaluation of hydroxynapthol blue. A color change caused by successful amplification of $X$. fastidiosa in the presence of HNB dye was readily distinguishable, with a clear shift from purple to a light blue (Fig. 2). PCR products from the HNB reaction were also run out on a gel for comparison (data not shown). There was no noticeable inhibition caused by the presence of the dye for samples $>500$ copies of template per reaction, with a color shift being observed within $60 \mathrm{~min}$. Lower concentrations of template, although producing the typical ladder pattern of successful amplification when examined by gel electrophoresis, did not trigger an identifiable color shift. The results showed that a minimum amount of template (250 to 500 copies) was required to trigger the color change.

Real-time PCR optimization. The real-time PCR assay targeting the rimM ORF was found to be robust over a range of annealing temperatures of 58 to $66^{\circ} \mathrm{C}$, although the highest reaction efficiency $\left(94.7 \%, r^{2}=0.993\right)$ was obtained with an annealing or extension stage of $62^{\circ} \mathrm{C}$. The addition of BSA was necessary to reduce inhibition from grapevine leaf samples (data not shown). The detection limit was observed to be $\approx 10$ copies/ reaction but there was considerable variation (standard deviation $>1$ cycle) between replicate $\mathrm{Ct}$ values for samples at this concen- 
tration. A concentration of 125 copies per reaction was the minimum titer needed for consistent amplification (standard deviation $<0.5$ cycle), with an average $\mathrm{Ct}$ value of $31.67 \pm 0.39$ cycles. The $X$. fastidiosa rimM real-time assay was comparable with the assay of Francis et al. (7) with regard to copy number detection but there was a decrease in $\mathrm{Ct}$ of 0.4 to 5.54 cycles for the rimM assay for many samples, suggesting that this target region amplifies more readily or that it is less susceptible to inhibitors present in extracts. The rimM assay also amplified two samples (Table 2) not detected by the assay of Francis et al. (7).

Comparison to extant methods. The specificity and sensitivity of the rimM LAMP and real-time assays compared favorably with the existing conventional (20) and real-time PCR (7) assays. Both the LAMP and rimM real-time assay amplified DNA from all $20 \mathrm{X}$. fastidiosa isolates tested. The pear leaf scorch isolate was not amplified by either assay. In comparison, the conventional PCR and Francis et al. (7) real-time assay amplified only 12 and 18 of the $20 \mathrm{X}$. fastidiosa isolates, respectively (Table 2 ). The pear leaf scorch isolate was amplified by the conventional
PCR but not by the Francis et al. (7) real-time PCR. X. fastidiosa was successfully detected from infected insect vectors by all assays (Table 2). No amplification was detected from nontarget bacterial species or healthy host species by either the LAMP or real-time PCR assays developed in this study.

For the LAMP and $\operatorname{rimM}$ real-time assay, amplification of $X$. fastidiosa DNA was successfully achieved from total DNA extracted from a range of infected plant hosts, from infected insect vectors, and from cultured bacterial cells. Although there was no identifiable inhibition from host tissue, the target titer in these samples was well above the limit of detection, with between $4 \times 10^{3}$ and $2.4 \times 10^{5}$ copies/ $\mu$ l as determined by real-time PCR. For the LAMP assay (in the absence of the HNB dye), the limit of detection was $\approx 250$ copies of template per reaction, compared with 10 copies for both real-time PCR assays and 500 copies for conventional PCR (Table 3); the conventional PCR results indicated a sensitivity to inhibitors present in $V$. vinifera extracts in particular, because it successfully amplified similar isolates from culture extracts but not from grape.

TABLE 2. Detection of Xylella fastidiosa from infected and healthy host plants, infected insects, and non-target bacterial species using the loop-mediated isothermal amplification (LAMP) and real-time and conventional polymerase chain reaction (PCR)

\begin{tabular}{|c|c|c|c|c|c|c|c|c|}
\hline Bacterial species & Host plant or insect species & $\begin{array}{l}\text { Country } \\
\text { of origin }\end{array}$ & Isolate & Source $^{a}$ & $\begin{array}{l}\operatorname{rim} M^{\mathrm{b}} \\
\mathrm{LAMP}\end{array}$ & $\mathrm{PCR}^{\mathrm{c}}$ & $\begin{array}{l}\operatorname{rim} M \\
\text { PCR }^{\mathrm{d}}\end{array}$ & $\begin{array}{l}\text { Real-time } \\
\text { PCR }^{\mathrm{e}}\end{array}$ \\
\hline \multirow{11}{*}{$\begin{array}{l}\text { Xylella fastidiosa } \\
\text { subsp. fastidiosa }\end{array}$} & & & & & & & & \\
\hline & Vitis vinifera & United States & DSMZ-10026 & DSMZ, Germany & + & + & $14.50 \pm 0.05$ & $15.03 \pm 0.07$ \\
\hline & $V$. vinifera & United States & PD0001 & L. Nunney, UC Riverside & + & - & $24.05 \pm 0.05$ & $25.76 \pm 0.22$ \\
\hline & $V$. vinifera & United States & PD0004 & L. Nunney, UC Riverside & + & + & $26.95 \pm 0.21$ & $25.76 \pm 0.15$ \\
\hline & $V$. vinifera & United States & & R. Almeida, UC Berkley & + & - & $19.84 \pm 0.05$ & $19.25 \pm 0.05$ \\
\hline & $V$. vinifera & United States & & R. Almeida, UC Berkley & + & - & $20.86 \pm 0.01$ & $20.46 \pm 0.18$ \\
\hline & Prunus dulcis & United States & ALS0005 & L. Nunney, UC Riverside & + & + & $26.20 \pm 0.03$ & $28.69 \pm 0.05$ \\
\hline & P. dulcis & United States & ALS0095 & L. Nunney, UC Riverside & + & + & $22.32 \pm 0.08$ & $25.54 \pm 0.57$ \\
\hline & P. dulcis & United States & ALS0096 & L. Nunney, UC Riverside & + & + & $23.26 \pm 0.01$ & $25.39 \pm 0.00$ \\
\hline & $V$. rotundifolia & United States & & C. Chang, UG & + & - & $24.54 \pm 0.18$ & $26.29 \pm 0.67$ \\
\hline & Graphocephala atropunctata & United States & & R. Almeida, UC Berkley & + & + & $30.52 \pm 0.23$ & $28.38 \pm 0.10$ \\
\hline \multirow[t]{7}{*}{ subsp. multiplex } & P. salicina & United States & ICMP-8375 & ICMP, Auckland, New Zealand & + & + & $17.34 \pm 0.14$ & $13.46 \pm 0.25$ \\
\hline & P. dulcis & United States & ICMP-6575 & ICMP, Auckland, New Zealand & + & + & $14.92 \pm 0.17$ & $14.98 \pm 0.19$ \\
\hline & P. dulcis & United States & ALS0003 & L. Nunney, UC Riverside & + & + & $25.51 \pm 0.75$ & $27.71 \pm 0.06$ \\
\hline & Quercus laevis & United States & OAK0023 & L. Nunney, UC Riverside & + & - & $25.92 \pm 0.23$ & $30.18 \pm 0.27$ \\
\hline & Q. rubra & United States & OAK0024 & L. Nunney, UC Riverside & + & - & $29.57 \pm 0.11$ & $\ldots$ \\
\hline & Q. rubra & United States & & C. Chang, UG & + & - & $17.82 \pm 0.29$ & $20.49 \pm 0.00$ \\
\hline & Liquidambar styraciflua & United States & LIQ0063 & L. Nunney, UC Riverside & + & - & $29.45 \pm 0.06$ & $\ldots$ \\
\hline \multirow[t]{3}{*}{ subsp. sandyi } & Nerium oleander & United States & OLS002 & L. Nunney, UC Riverside & + & + & $19.35 \pm 0.04$ & $22.63 \pm 0.27$ \\
\hline & N. oleander & United States & OLS008 & L. Nunney, UC Riverside & + & + & $21.45 \pm 0.02$ & $25.21 \pm 0.63$ \\
\hline & N. oleander & United States & OLS009 & L. Nunney, UC Riverside & + & + & $27.17 \pm 0.22$ & $33.01 \pm 0.40$ \\
\hline subsp. pauca & Citrus sp. & Brazil & $9 \mathrm{a} 5 \mathrm{C}$ & H. Coletta Filho, CDC Brazil & + & + & $15.86 \pm 0.19$ & $16.04 \pm 0.07$ \\
\hline Unspecified subsp. & Pyrus sp. & Taiwan & & C. Su, TACTRI, Taiwan & - & + & $\ldots$ & $\ldots$ \\
\hline \multicolumn{8}{|c|}{ Xanthomonas } & \\
\hline $\begin{array}{l}\text { aurantifolii } \\
X . \text { campestris }\end{array}$ & $\cdots$ & Brazil & ICMP 14285 & ICMP, Auckland, New Zealand & - & - & $\cdots$ & $\cdots$ \\
\hline \multirow[t]{2}{*}{ pv. citri } & $\ldots$ & United States & ICMP 10012 & ICMP, Auckland, New Zealand & - & - & $\ldots$ & $\ldots$ \\
\hline & $\ldots$ & New Zealand & ICMP 24 & ICMP, Auckland, New Zealand & - & - & $\ldots$ & $\ldots$ \\
\hline \multicolumn{9}{|l|}{$X$. arboricola } \\
\hline pv. fragariae & $\ldots$ & Italy & ICMP 17064 & ICMP, Auckland, New Zealand & - & - & $\ldots$ & $\cdots$ \\
\hline \multicolumn{9}{|l|}{ Pseudomonas } \\
\hline pv. persicae & $\ldots$ & New Zealand & ICMP 7090 & ICMP, Auckland, New Zealand & - & - & $\ldots$ & $\ldots$ \\
\hline \multicolumn{9}{|l|}{ Pantoea } \\
\hline agglomerans & $\ldots$ & New Zealand & $\ldots$ & MAF Collection, New Zealand & - & - & $\ldots$ & $\ldots$ \\
\hline \multicolumn{9}{|l|}{ Agrobacterium } \\
\hline tumefaciens & $\ldots$ & New Zealand & $\ldots$ & M. Pearson, Univ. Auckland & - & - & $\ldots$ & $\ldots$ \\
\hline Spiroplasma citri & $\ldots$ & United States & $\ldots$ & R. Yokomi, USDA-ARS & - & - & $\ldots$ & $\ldots$ \\
\hline \multicolumn{9}{|l|}{ Healthy host } \\
\hline species & V. vinifera & New Zealand & $\ldots$ & MAF Collection, New Zealand & - & - & $\ldots$ & $\ldots$ \\
\hline & $V$. rotundifolia & United States & $\ldots$ & C. Chang, UG & - & - & $\ldots$ & $\ldots$ \\
\hline & $P$. persica & New Zealand & $\ldots$ & MAF Collection, New Zealand & - & - & $\ldots$ & $\ldots$ \\
\hline & Citrus latifolia & New Zealand & $\ldots$ & MAF Collection & - & - & $\ldots$ & $\ldots$ \\
\hline
\end{tabular}

${ }^{a} \mathrm{UC}=$ University of California, UG = University of Georgia, USDA-ARS = United States Department of Agriculture-Agricultural Research Service.

${ }^{\mathrm{b}}$ LAMP detection: $+=$ positive and $-=$ negative.

${ }^{c}$ Minsavage et al. (20). Conventional PCR: $+=$ positive and $-=$ negative.

d rimM real-time PCR. Real-time PCR results with a crossing threshold value of $>38$ cycles were considered negative.

e Francis et al. (7) real-time PCR. Real-time PCR results with a crossing threshold value of $>38$ cycles were considered negative. 
Testing alternative DNA extraction methods for field use. Two alternative DNA extraction methods for plant tissue were compared with the standard DNeasy (Qiagen) column-based method to establish whether extractions could be done in the field. DNA extracted from infected lyophilized tissue of $V$. vinifera, $V$. rotundifolia, and $Q$. rubra was tested using the LAMP and the rimM real-time PCR assays developed in this study. PCR competency was checked using a real-time internal control assay for the plant cytochrome oxidase (COX) gene (38); results are presented in Table 4. Neither the COX internal control or $X$. fastidiosa were amplified from DNA extracted using the ExtractN-Amp method (Sigma-Aldrich), whereas the PickPen/Invimag (Bio-Nobile/Invitek) protocol worked effectively. Samples amplified an average of 0.40 cycles earlier for COX and 6.45 cycles earlier for X. fastidiosa using the DNeasy (Qiagen) compared with the PickPen (Bio-Nobile) method, suggesting that, although field extraction by PickPen is possible, it may not be as effective as the column-based technique for recovering low titers of $X$. fastidiosa DNA.

\section{DISCUSSION}

From a quarantine perspective, the ability to exclude important regulated plant pathogens or undertake surveillance depends on rapid and reliable methods of detection. These methods must be easily transferable between laboratories and, if possible, be suitable for use in the field. The objective of this work was to develop such a diagnostic method for X. fastidiosa. LAMP (23, 24) seemed to be an appropriate method, because it has been used to amplify and detect plant-pathogenic bacteria, fungi, viruses, and nematodes $(8,15,16,25,35,37)$ as well as human and animal pathogens $(6,14)$. The reaction can potentially be performed in the field because minimal equipment is needed to run the reaction and positive reactions can be identified visually using colorimetric dyes (9).

Assay design made use of the recent advances in $X$. fastidiosa genomic information $(4,5,36)$. The two assays developed, LAMP and real-time PCR, both target the $16 \mathrm{~S}$ rRNA processing protein gene $(\operatorname{rim} M)$ that is conserved between all genomic sequences of $X$. fastidiosa but is sufficiently distant from related xanthomonad species. Many other regions targeted by extant PCR-based detection methods are strain or subspecies specific $(2-4,12)$. In contrast to existing PCR assays, both the LAMP and the new realtime assay detected all $20 \mathrm{X}$. fastidiosa isolates tested, representing the four major subspecies. In addition, the assays were able to detect the bacterium from infected insect vectors. The pear leaf scorch isolate was not amplified by either real-time or LAMP assays, which is unsurprising given the genetic divergence between this and other extant X. fastidiosa strains (19) but, curiously, was amplified by the conventional PCR.
The conventional PCR (20) is still used routinely for quarantine purposes in several countries. However, the assay does not detect all isolates of $X$. fastidiosa and the sequences that have been published since its development should be incorporated into the design of new primers $(5,36)$.

The LAMP assay is highly specific and shows greater sensitivity than conventional PCR. However, it is not as sensitive as real-time PCR, which is consistent among LAMP assays designed for plant bacterial and viral pathogens $(8,16,25,33,37)$. The level of sensitivity ( $\approx 500$ copies of template per reaction) obtained by LAMP is acceptable for first-instance screening, although with the caveat that samples of marginal titer or of poor DNA quality may be missed. Application of an internal control such as COX would reduce the likelihood of false-negative results caused by the latter. It was noted during assay development using X. fastidiosa DNA diluted in water versus dilution in healthy grapevine DNA that the LAMP assay was less sensitive to inhibition than conventional and real-time PCR (S. J. Harper, unpublished).

Both the LAMP and real-time PCR assays are rapid, being able to detect $X$. fastidiosa extracted from infected tissue using a simple magnetic-bead based method in $\approx 1 \mathrm{~h}$, similar to that described previously for real-time PCR $(29,32)$. The assays diverge considerably in equipment requirements. LAMP can be conducted in a water-bath or heat-block; although real-time PCR can be used in the field (34), this method requires an expensive specialized portable thermocycler. The LAMP method may be assessed using a range of endpoint detection methods, including magnesium pyrophosphate accumulation (22), colorimetric hydroxynapthol blue dye (9), fluorescent intercalating dyes such as SYBR Green (Molecular Probes, Inc., Eugene, OR) or PicoGreen (Molecular Probes, Inc.) (32), precipitation with cationic

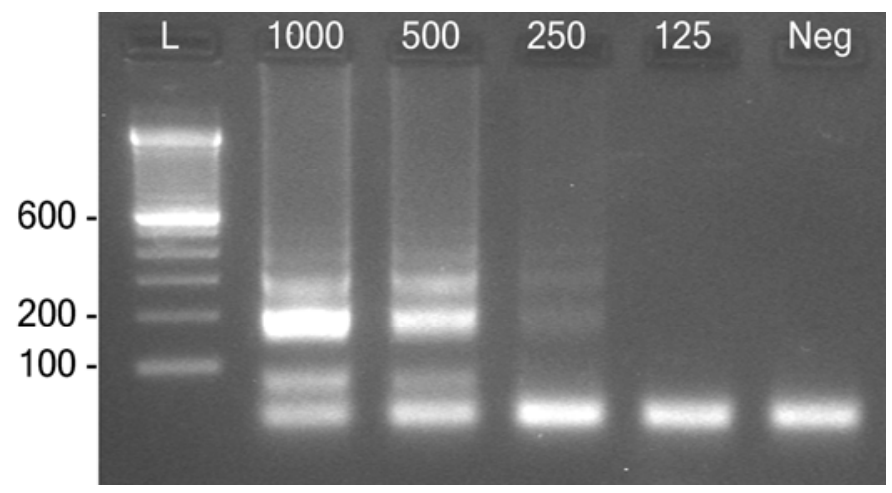

Fig. 1. Results of rimM loop-mediated isothermal amplification of serially diluted Xylella fastidiosa DNA (copy numbers of 1,000 to 125, diluted in healthy Vitis vinifera DNA extract) after $60 \mathrm{~min}$ of incubation at $65^{\circ} \mathrm{C}$. Neg $=$ healthy $V$. vinifera DNA extract and $\mathrm{L}=$ Invitrogen 100-bp ladder.

TABLE 3. Comparison of the sensitivity of the Xylella fastidiosa rimM loop-mediated isothermal amplification (LAMP) and real-time polymerase chain reaction (PCR) assays against published real-time and conventional PCR assays

\begin{tabular}{|c|c|c|c|c|c|c|c|c|c|}
\hline \multirow[b]{3}{*}{ Copies $^{\mathrm{a}}$} & \multicolumn{6}{|c|}{$\operatorname{rim} M \mathrm{LAMP}^{\mathrm{b}}$} & \multirow[b]{3}{*}{$\operatorname{rim} M \mathrm{PCR}^{\mathrm{c}}$} & \multirow[b]{3}{*}{ Real-time $\mathrm{PCR}^{\mathrm{d}}$} & \multirow[b]{3}{*}{$\mathrm{PCR}^{\mathrm{e}}$} \\
\hline & \multicolumn{2}{|c|}{$45 \mathrm{~min}$} & \multicolumn{2}{|c|}{$60 \mathrm{~min}$} & \multicolumn{2}{|c|}{$75 \mathrm{~min}$} & & & \\
\hline & Gel & $\mathrm{HNB}$ & Gel & HNB & Gel & HNB & & & \\
\hline 1,000 & +-- & ++- & +++ & +++ & +++ & +++ & $28.61 \pm 0.09$ & $29.82 \pm 0.13$ & ++ \\
\hline 500 & - & - & +++ & ++- & +++ & +++ & $29.64 \pm 0.05$ & $30.93 \pm 0.07$ & ++ \\
\hline 250 & - & - & ++- & $?--$ & +++ & +++ & $30.52 \pm 0.19$ & $31.84 \pm 0.11$ & $?-$ \\
\hline 125 & - & - & - & - & $+? ?$ & +-- & $31.67 \pm 0.39$ & $32.82 \pm 0.14$ & - \\
\hline 10 & - & - & - & - & - & - & $35.77 \pm 1.62$ & $37.84 \pm 0.32$ & - \\
\hline Negative & - & - & - & - & - & - & - & - & - \\
\hline
\end{tabular}

a Copies per reaction.

b LAMP sensitivity: + = positive; - = negative; ? = weakly positive for hydroxynapthol blue (HNB).

c rimM real-time PCR. Real-time PCR results with a crossing threshold value of $>38$ cycles were considered negative.

${ }^{\mathrm{d}}$ Francis et al. (7) real-time PCR. Real-time PCR results with a crossing threshold value of $>38$ cycles were considered negative.

e Minsavage et al. (20). Conventional PCR: + = positive; $-=$ negative; and ? = weakly positive by gel electrophoresis. 
polymers (21), lateral flow devices with labeled primers (35), and gel electrophoresis. Magnesium pyrophosphate detection can be difficult to determine visually (14), while the latter four methods require the tubes to be opened post amplification, yet opening the tubes leads to a risk of aerosol contamination due to the high titer of the LAMP amplicon (31). HNB allows visual detection and is added prior to amplification, which allows the reaction to be performed as a closed-tube system. During this study, HNB required at least 500 copies of target template to trigger color change within an hour; therefore, there is a risk that very low titers of $X$. fastidiosa may not be detected. Increasing the reaction time to $75 \mathrm{~min}$ did improve the likelihood of detecting lower concentrations of target DNA; however, reaction times $>75 \mathrm{~min}$ did not improve the sensitivity of the assay.

A consideration for field-based detection with any assay is DNA extraction. Standard laboratory-based methods are not easily applied in the field due to the need for specialized equipment, and many of the field-based methods proposed are specific to each host-pathogen system $(17,34)$. Being xylem-limited, $X$. fastidiosa presents a particular difficulty for field-based extraction because physical disruption of the tissue or extraction of sap is required (29). In this study, the Extract-N-Amp method which relies on thermal and chemical degradation failed to extract viable DNA, whereas homogenization with a hand-roller and DNA extraction using magnetic beads with a hand-held device (PickPen; Bio-Nobile) was sufficient to extract $X$. fastidiosa DNA from lyophilized samples. Only lyophilized tissue was available for this study; therefore, a comparison could not be made with the sap extraction protocol of Schaad et al. (29). Using the PickPen extraction, the titer of extracted $X$. fastidiosa DNA was, on average, 100-fold lower than in samples extracted using the Qiagen DNeasy system, as evidenced by lower $\mathrm{Ct}$ values for the Qiagen DNeasy extracts, although Ct values for the COX internal control were not markedly different between the extraction types. Such a loss of sensitivity may cause false-negative results for samples of marginal titer. Further extractions using fresh tissue may give a better indication of the performance of the PickPen method, and the use of additives to reduce the presence of inhibitors should be investigated.

Finally, the cost of each of the assays tested may be considered. The LAMP assay, with its requirement for specialized enzymes and reagents (especially dNTP usage and the need for HPLCpurified inner primers) costs $\approx \$ 5.30$ USD (at time of writing) compared with $\approx \$ 1.00$ USD for conventional and real-time PCR. However, this does not include the cost of specialized equipment such as real-time thermocyclers. The cost of LAMP may be a limitation for large-scale surveys and, for such applications, realtime PCR may be more cost effective. Despite this, LAMP offers a time-saving advantage if reactions are to be carried out in the field, and using LAMP in situ may reduce the need to move infected tissue across country for laboratory testing.

Both the LAMP and the rimM real-time PCR assays have a high level of specificity for the detection and diagnosis of the major subspecies of $X$. fastidiosa. Provided that care is taken to avoid contamination by using LAMP as a closed-tube assay (31) with colorimetric reporter dyes such as HNB, LAMP has the

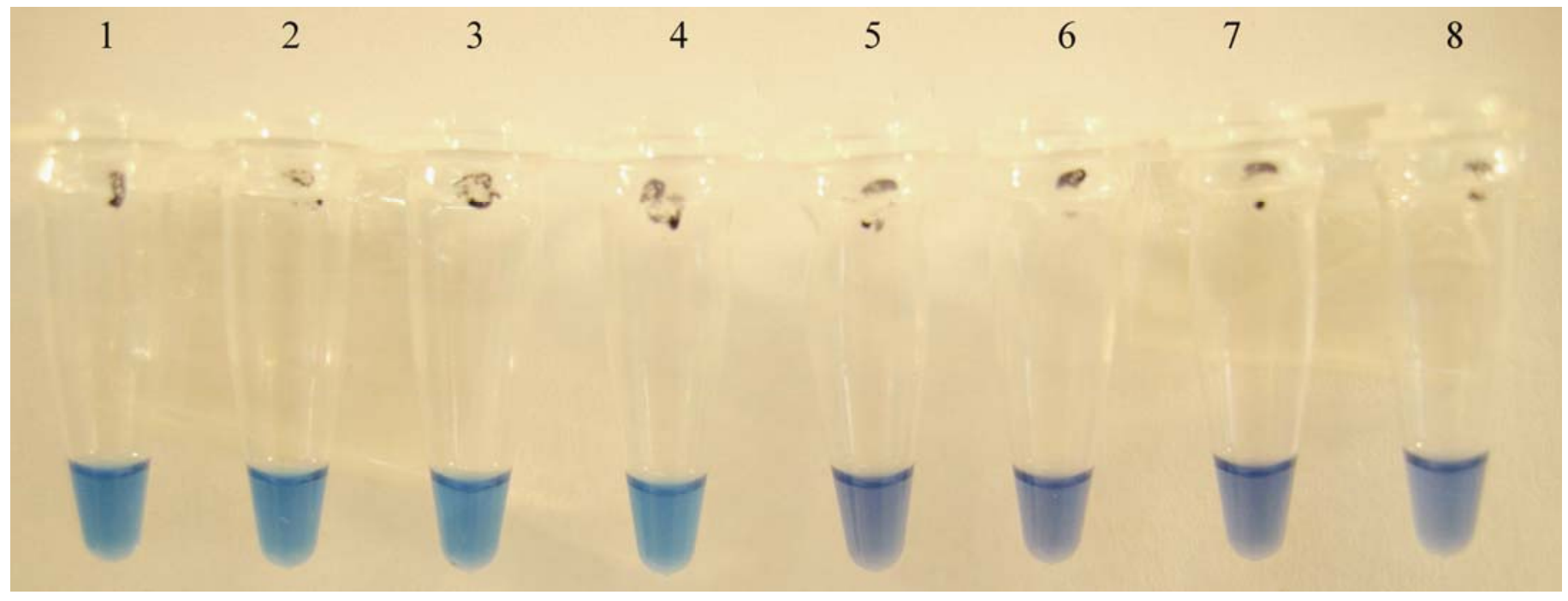

Fig. 2. Successful rimM loop-mediated isothermal amplification visualized using hydroxynapthal blue dye showing the sky-blue color change (tubes 1 to 4 ) observed with Xylella fastidiosa-positive samples. Negative samples in which no amplification occurred remain violet (tubes 5 to 8).

TABLE 4. Comparison of field-based extraction methods (BioNoble PickPen or Invimag DNA reagents and Sigma-Aldrich Extract-N-Amp) to the Qiagen DNeasy method, assessed using Xylella fastidiosa rimM loop-mediated isothermal amplification (LAMP) $(+=$ positive and $-=$ negative) and real-time polymerase chain reaction (PCR) assays and a cytochrome oxidase (COX) internal control assay to show PCR competency

\begin{tabular}{|c|c|c|c|c|}
\hline \multirow[b]{2}{*}{ Source of material } & \multirow[b]{2}{*}{ Extraction method } & \multicolumn{3}{|c|}{ Test } \\
\hline & & LAMP & Real-time PCR ${ }^{\mathrm{a}}$ & $\mathrm{COX}^{\mathrm{a}}$ \\
\hline \multirow[t]{3}{*}{ Vitis vinifera $\mathrm{cv}$. Cabernet Sauvignon } & DNeasy & + & $20.86 \pm 0.01$ & $16.63 \pm 0.16$ \\
\hline & PickPen w/Invimag Kit & + & $28.45 \pm 0.11$ & $20.00 \pm 0.49$ \\
\hline & Sigma Extract n’ Amp & - & & \\
\hline \multirow{3}{*}{$V$. rotundifolia } & DNeasy & + & $24.54 \pm 0.18$ & $21.23 \pm 0.22$ \\
\hline & PickPen w/Invimag Kit & + & $30.19 \pm 0.03$ & $20.83 \pm 0.03$ \\
\hline & Sigma Extract n’ Amp & - & & \\
\hline \multirow[t]{3}{*}{ Quercus rubra } & DNeasy & + & $17.82 \pm 0.29$ & $17.59 \pm 0.03$ \\
\hline & PickPen w/Invimag Kit & + & $22.39 \pm 0.22$ & $16.17 \pm 0.53$ \\
\hline & Sigma Extract n’ Amp & - & $\ldots$ & $\ldots$ \\
\hline
\end{tabular}

a Real-time PCR results with a crossing threshold value of $>38$ cycles were considered negative. 
potential to be used in the field. Initial work comparing extraction methods suggests that there is a suitable extraction method that can be used alongside LAMP in situ. The method described here should be readily transferable to other laboratories due to the fact that expensive specialized equipment is not required. It is estimated that a reasonable number of samples $(>50)$ could be processed or screened within $2 \mathrm{~h}$ in the field.

\section{ACKNOWLEDGMENTS}

We thank C. Chang, R. Almeida, and L. Nunney for providing $X$. fastidiosa samples; N. Boonham and J. Tomlinson (Food and Environment Research Agency, York, UK) for help and assistance in developing the LAMP assay and the PickPen extraction method; and MAF Biosecurity New Zealand Operational Research for funding this work.

\section{LITERATURE CITED}

1. Berisha, B., Chen, Y. D., Zhang, G. Y., Xu, B. Y., and Chen, T. A. 1998. Isolation of Pierce's disease bacteria from grapevines in Europe. Eur. J. Plant Pathol. 104:427-433.

2. Blexine, B., and Child, B. 2007. Xylella fastidiosa genotype differentiation by SYBR green-based qRT-PCR. FEMS Microbiol. Lett.276:48-54.

3. Chen, J., Banks, D., Jarret, R. L., Chang, C. J., and Smith, B. J. 2000. Use of $16 \mathrm{~S}$ rDNA sequences as signature characters to identify Xylella fastidiosa. Curr. Microbiol. 40:29-33.

4. Chen, J., Civolero, E., Tubajika, K., Livingston, S., and Higbee, B. 2008. Hypervariations of a protease-encoding gene, PD0218 ( $p s p B)$, in Xylella fastidiosa strains causing Almond leaf scorch and Pierce's disease in California. Appl. Environ. Microbiol. 74:3652-3657.

5. Doddapaneni, H., Yao, J., Lin, H., Walker, M. A., and Civolero, E. L. 2006. Analysis of the genome-wide variations among multiple strains of the plant pathogenic bacterium Xylella fastidiosa. BMC Genomics 7:225-240.

6. Dukes, J. P., King, D. P., and Alexandersen, S. 2006. Novel reversetranscription loop-mediated isothermal amplification for rapid detection of foot-and-mouth disease virus. Arch. Virol. 151:1093-1106.

7. Francis, M., Lin H., Cabrera-La Rosa J., Doddapaneni H., and E. L., C. 2006. Genome-based PCR primers for specific and sensitive detection and quantification of Xylella fastidiosa. Eur. J. Plant Pathol. 115:203-213.

8. Fukuta, S., Mizikami, Y., Ishida, A., Ueda, J., Kanabe, M., and Ishimoto, Y. 2003. Detection of Japanese yam mosaic virus by RT-LAMP. Arch. Virol. 148:1713-1720.

9. Goto, M., Honda, E., Ogura, A., Nomoto, A., and Hanaki, K. 2009. Colormetric detection of loop mediated isothermal amplification reaction by using hydroxy napthol blue. Biotechnqiues 46:167-172.

10. Hendson, M., Purcell, A. H., Chen, D., Smart, C., Guilhabert, M., and Kirkpatrick, B. 2001. Genetic diversity of Pierce's disease strain and other pathotypes of Xylella fastidiosa. Appl. Environ. Microbiol. 67:895-903.

11. Hopkins, D. L., and Purcell, A. H. 2002. Xylella fastidiosa: cause of Pierce's disease of grapevine and other emergent diseases. Plant Dis. 86:1056-1066.

12. Huang, Q. 2009. Specific detection and identification of Xylella fastidiosa strains causing oleander leaf scorch using polymerase chain reaction. Curr. Microbiol. 58:393-398

13. Huang, Q., Bentz, J., and Sherald, J. L. 2006. Fast, easy and efficient DNA extraction and one-step polymerase chain reaction for the detection of Xylella fastidiosa in potential insect vectors. J. Plant Pathol. 88:77-81.

14. Iwamoto, T., Sonobe, T., and Hayashi, K. 2003. Loop-mediated isothermal amplification for direct detection of Mycobacterium tuberculosis complex, M. avium, and $M$. intracellulare in sputum samples. J. Clin. Microbiol. 41:2616-2622.

15. Kikuchi, T., Aikawa, T., Oeda, Y., Karim, N., and Kanzaki, N. 2009. A rapid and precise diagnostic method for detecting the pinewood nematode Bursaphelenchus xylophilus by loop-mediated isothermal amplification. Phytopathology 99:1365-1369.

16. Kubota, R., Vine, B. G., Alvarez, A. M., and Jenkins, D. M. 2008. Detection of Ralstonia solanacaerum by loop-mediated isothermal amplification. Phytopathology 98:1045-1051.

17. Kuske, C. R., Banton, K. L., Adorada, D. L., Stark, P. C., Hill, K. K., and Jackson, P. J. 1998. Small-scale DNA sample preparation method for field PCR detection of microbial cells and spores in soil. Appl. Environ. Microbiol. 64:2463-2472.

18. Leu, L. S., and Su, C. C. 1993. Isolation, cultivation, and pathogenicity of Xylella fastidiosa, the causal bacterium of pear leaf scorch disease in Taiwan. Plant Dis. 77:642-646.

19. Mehta, A., and Rosato, Y. 2001. Phylogenetic relationships of Xylella fastidiosa strains from different hosts, based on 16S rDNA and 16S-23S intergenic spacer sequences. Int. J. Syst. Evol. Microbiol. 51:311-318.

20. Minsavage, G. V., Thompson, C. M., Hopkins, D. L., Leite, R. M. V. B. C., and Stall, R. E. 1994. Development of a polymerase chain reaction protocol for detection of Xylella fastidiosa in plant tissue. Phytopathology 84:456-461.

21. Mori, Y., Hirano, T., and Notomi, T. 2006. Sequence specific visual detection of LAMP reactions by addition of cationic polymers. BMC Biotechnol. 6:3.

22. Mori, Y., Nagamine, K., Tomita, N., and Notomi, T. 2001. Detection of loop-mediated isothermal amplification reaction by turbidity derived from magnesium pyrophosphate formation. Biochem. Biophys. Res. Commun. 289:150-154.

23. Nagamine, K., Hase, T., and Notomi, T. 2002. Accelerated reaction by loop-mediated isothermal amplification using loop primers. Mol. Cell. Probes 16:223-229.

24. Notomi, T., Okayama, H., Masubuchi, H., Yonekawa, T., Watanabe, K., Amino, N., and Hase, T. 2000. Loop-mediated isothermal amplification of DNA. Nucleic Acids Res. 28:E63.

25. Okuda, M., Matsumoto, M., Takana, Y., Subandiah, S., and Iwanami, T. 2005. Characterization of the $t u f \mathrm{~B}-s e c \mathrm{E}-n u s \mathrm{G}-r p l \mathrm{KAJL}-r p o \mathrm{~B}$ gene cluster of the citrus greening organism and detection by loop-mediated isothermal amplification. Plant Dis. 89:705-711.

26. Pooler, M. R., and Hartung, J. S. 1995. Genetic relationships among strains of Xylella fastidiosa from RAPD-PCR data. Curr. Microbiol. 31:134-137.

27. Purcell, A. H. 1997. Xylella fastidiosa, a regional problem or global threat? J. Plant Pathol. 79:99-105.

28. Rodrigues, J. L. M., Silva-Stenico, M. E., Gomes, J. E., Lopes, J. R. S., and Tsai, S. M. 2003. Detection and diversity assessment of Xylella fastidiosa in field-collected plant and insect samples by using 16S rRNA and gyrB sequences. Appl. Environ. Microbiol. 69:4249-4255.

29. Schaad, N. W., Opgenorth, D., and Gaush, P. 2002. Real-time polymerase chain reaction for one-hour on-site diagnosis of Pierce's disease of grape in early season asymptomatic vines. Phytopathology 92:721-728.

30. Speiss, A. N., Mueller, N., and Ivell, R. 2004. Trehalose is a potent PCR enhancer: Lowering of DNA melting temperature and thermal stabilization of Taq polymerase by the disaccharide trehalose. Clin. Chem. 50:1256-1259.

31. Tomita, N., Mori, Y., Kanda, H., and Notomi, T. 2008. Loop-mediated isothermal amplification (LAMP) of gene sequences and simple visual detection of products. Nat. Protocols 3:877-882.

32. Tomlinson, J., Barker, I., and Boonham, N. 2007. Faster, simpler, morespecific methods for improved molecular detection of Phytophthora ramorum in the field. Appl. Environ. Microbiol. 73:4040-4047.

33. Tomlinson, J., and Boonham, N. 2008. Potential of LAMP for detection of plant pathogens. Commonw. Agric. Bur. Rev. Perspect. Agric. Vet. Sci. Nutr. Nat. Resour. 3:1-7.

34. Tomlinson, J. A., Boonham, N., Hughes, K. J. D., Griffin, R. L., and Barker, I. 2005. On-site DNA extraction and real-time PCR for detection of Phytophthora ramorum in the field. Appl. Environ. Microbiol. 71:6702-6710.

35. Tomlinson, J. A., Dickinson, M. J., and Boonham, N. 2010. Rapid Detection of Phytophthora ramorum and P. kernoviae by two-minute DNA extraction followed by isothermal amplification and amplicon detection by generic lateral flow device. Phytopathology 100:143-149.

36. Van Sluys, M. A., de Oliveira, M. C., Monteiro-Vitorello, C. B., Miyaki, C. Y., Furlan, I. R., Camargo, L. E. A., da Silva, A. C. R., Moon, D. H., Takita, M. A., Lemos, E. G. M., Machado, M. A., Ferro, M. I. T., da Silva, F. R., Goldman, M. H. S., Goldman, G. H., Lemos, M. V. F., El-Dorry, H., Tsai, S. M., Carrer, H., Carraro, D. M., de Oliveira, R. C., Nunes, L. R., Siqueira, W. J., Coutinho, L. L., Kimura, E. T., Ferro, E. S., Harakava, R., Kuramae, E. E., Marino, C. L., Giglioti, E., Aberu, I. L., Alves, L. M. C., do Amaral, A. M., Baia, G. S., Blanco, S. R., Brito, M. S., Cannavan, S., Celestino, A. V., da Cunha, A. F., Fenille, R. C., Ferro, J. A., Formighieri, E. F., Kishi, L. T., Leoni, S. G., Oliveira, A. R., Rosa, V. E., Sassaki, F. T., Sena, J. A. D., de Souza, A. A., Truffi, D., Tsukumo, F., Yanai, G. M., Zaros, L. G., Civolero, E. L., Simpson, A. J. G., Alameida, N. F., Setubal, J. C., and Kitajima, J. P. 2003. Comparative analyses of the complete genome sequences of Pierce's disease and citrus variegated chlorosis strains of Xylella fastidiosa. J. Bacteriol. 185:1018-1026.

37. Varga, A., and James, D. 2006. Use of reverse transcription loop-mediated isothermal amplification for the detection of Plum pox virus. J. Virol. Methods 138:184-190.

38. Weller, S. A., Elphinstone, J. G., Smith, N. C., Boonham, N., and Stead, D. E. 2000. Detection of Ralstonia solanacearum strains with a quantitative, multiplex, real-time, fluorogenic PCR (TaqMan) assay. Appl. Environ. Microbiol. 66:2853-2858.

39. Wells, J. M., Raju, B. C., Hung, H. Y., Weisberg, W. G., Mandelco-Paul, L., and Brenner, D. J. 1987. Xylella fastidiosa gen. nov., sp. nov: gramnegative, xylem-limited, fastidious plant bacteria related to Xanthomonas spp. Int. J. Syst. Bacteriol. 37:136-143. 
Erratum

The probe sequence was corrected on page 1283, Table 1, to TCGCATCCCGTGGCTCAGTCC. Changes to this article were made on May 16, 2013. 